\title{
Energy Management Strategies for Hybrid PV/Diesel Energy Systems: Simulation and Experimental Validation
}

\author{
Gabin Koucoi ${ }^{1}$, Daniel Yamegueu ${ }^{1}$, , Quoc-Tuan $\operatorname{Tran}^{2}$, Yézouma Couliblay ${ }^{1}$, Hervé Buttin ${ }^{2}$ \\ ${ }^{1}$ Laboratory for Solar Energy and Energy Savings (LESEE), International Institute for Water and Environmental Engineering (2IE), \\ Ouagadougou, Burkina Faso \\ ${ }^{2}$ Smart Grid Laboratory (LSEI), National Solar Energy Institute (CEA/INES), Bourget Du Lac, France
}

\author{
Email address: \\ dan.yamegueu@gmail.com (D. Yamegueu)
}

\section{To cite this article:}

Gabin Koucoi, Daniel Yamegueu, Quoc-Tuan Tran, Yézouma Couliblay, Hervé Buttin. Energy Management Strategies for Hybrid PV/Diesel Energy Systems: Simulation and Experimental Validation. International Journal of Energy and Power Engineering.

Vol. 5, No. 1, 2016, pp. 6-14. doi: 10.11648/j.jijepe.20160501.12

\begin{abstract}
Hybrid photovoltaic-diesel systems are becoming more and more attractive for rural electrification in sub-Saharan Africa region. In this paper, some energy management strategies for a photovoltaic-diesel system without battery storage have been theoretically and experimentally studied. The proposed strategies are respectively based on active power control of inverters and controllable loads to ensure security operation for the system and maximize the solar energy penetration. Simulations and experiments have been performed under two different climate conditions and have been applied to an African rural load profile. All the energy management strategies developed have been implemented with the Matlab environment. The obtained results have shown the effectiveness of the proposed strategies to avoid power reserve to the diesel generator, to increase solar energy fraction, to reduce $\mathrm{CO}_{2}$ emissions, and to ensure the system's frequency and voltage stability.
\end{abstract}

Keywords: Hybrid PV/Diesel System, Simulation, Experimentation, Energy Management, Off-Grid Electrification

\section{Introduction}

At a worldwide level, between 1.7 and 2.0 billion people do not have access to public grid-based electricity. The majority of this population lives in rural areas $[1,2]$. In fact, grid extension is often considered as the first option for the electrification of these areas. However, electrification by grid extension requires a large investment that generally does not coincide with disperse populations with low energy demands and low income. Despite many efforts to extend the existing grids to rural areas, most remote areas will not be reached within a foreseeable future. The electrification rate of subSaharan Africa is one of the lowest among developing countries. The situation is more catastrophic in rural areas where less than $18 \%$ of population have access to electricity [3]. Furthermore, the progressive electrification of such rural areas has mainly been achieved through stand-alone energy production units and widely by Diesel generators (DG). However, the volatile prices of fossil fuels, their high cost of maintenance coupled to their greenhouse gas emissions make this option costly and unsustainable [4, 5]. Fortunately, these regions have abundant solar energy potential ranging from 4 to $6 \mathrm{kWh} / \mathrm{m}^{2} /$ day which is enough to develop solar energy power generation systems $[4,5]$. As shown by many authors, PV/Diesel hybrid systems can be more reliable and cost effective than stand-alone PV or Diesel systems. It could be a great opportunity for rural electrification that could trigger social and economic development in rural areas [4-6].

However most of these hybrid energy systems included a battery storage system. Due to manifold drawbacks of batteries, namely their high investment and replacement costs, their short lifetime (between 3 and 5 years maximum in rural areas for solar lead-acid batteries which are commonly used for PV systems), and their chemical pollution of the environment (batteries are released into nature after their use because of the lack of recycling infrastructure for batteries in developing countries), hybrid PV/Diesel systems without batteries for storage for rural electrification are being considered more often [4, 7]. Furthermore, in a hybrid PV/Diesel system without battery, an energy management system is mandatory to increase their reliability and their optimal operation. Many studies have been published and demonstrated that there is a potential for hybrid systems based on PV/Diesel system but very few 
include experimental verification of the system behavior [5, 8 , 9]. In this paper, energy management strategies based respectively on inverter active power control and on controllable loads using are proposed and compared to inverter ON/OFF control strategy from simulation and experimental analysis. First, the control strategies studied are described followed by the models of the system' components used for simulation. Second, the experimental setup and case of study considered are displayed. Then, the results from simulation and experimental validation are presented and discussed. Finally, the conclusion is made.

\section{Description of Energy Management Strategies for Hybrid PV/Diesel Energy Systems}

The hybrid PV/Diesel energy system studied in this work includes a diesel generator coupled with a PV inverter to supply a load profile demand. In the following subsection, the different energy management strategies studied are described.

\subsection{Energy Management Strategy Based on Inverter ON/OFF Control}

This strategy called "Inverter ON/OFF control" aims to control the hybrid PV/Diesel system by switching ON or OFF the inverter according to climate conditions and load variation. Figure 1 shows the flowchart of this control strategy. As displayed in Figure 1, the inverter is switch OFF when the remaining power to be supplied by the diesel generator is less than its minimal output power value (P Diesel_min $_{\text {, }}$, the inverter is set OFF to avoid DG to operate under this limit.

Based on the PV array power (Ppv (t)) measurement the inverter is kept connected to the system whenever the DG output power is higher than it minimal output power value.

$\mathrm{X}_{\text {Inverter }}=0$ means that the inverter is disconnected from the system. When $\mathrm{X}_{\text {Inverter }}=1$, the inverter is connected and the load will be fed by both inverter and diesel generator.

This control strategy based on PV inverter switching is the simplest approach to control PV energy penetration on a hybrid system. However this approach could lead to a waste of a significant amount of the PV energy produced.

To overcome this drawback, we proposed in what follows two new strategies, which aim to achieve more PV energy integration in the energy system and to guarantee reliable operation of the whole system.

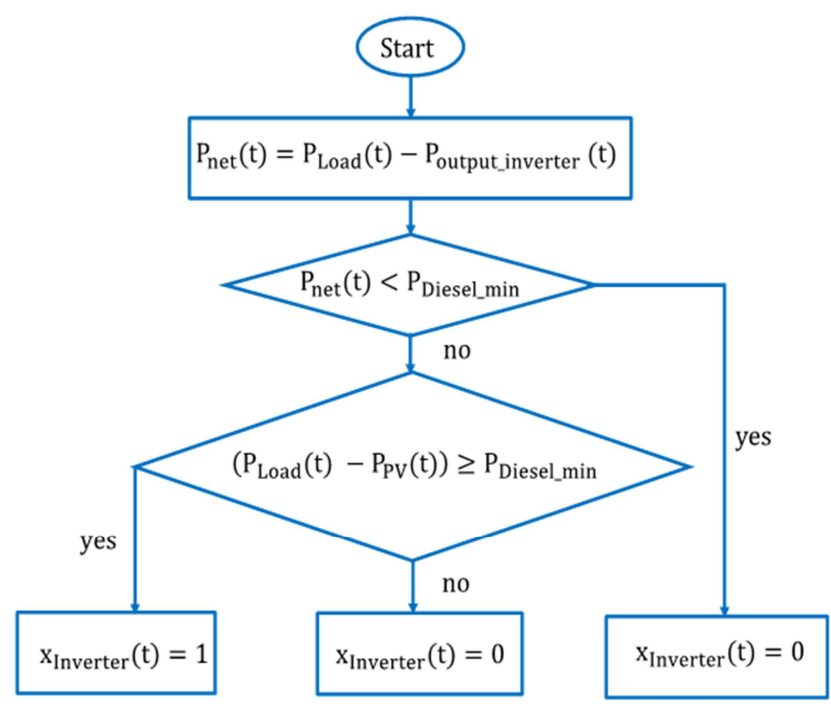

Figure 1. Flowchart of inverter ON/OFF control strategy.

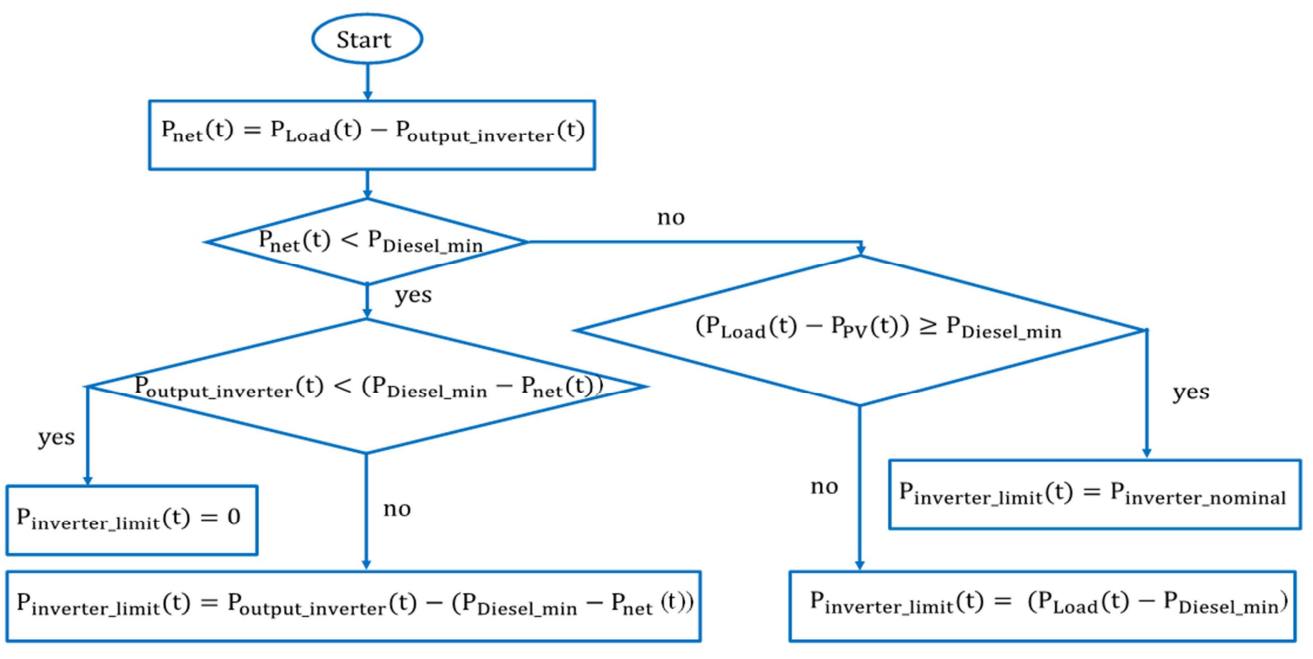

Figure 2. Flowchart of inverter active power control.

\subsection{Energy Management Strategy Based on Inverter Active Power Control}

Whatever climate conditions and load variations, the hybrid PV/Diesel system is expected to deliver energy without interruption at any time and ensure a stability of the system. This energy management strategy shown on Figure 2 aims to ensure reliable operation of the system, to maximize the solar energy penetration by the inverter's active power control and to avoid operation of the DG under its minimal 
set point value especially during high PV generation and low loads periods.

According to the algorithm shown on Figure 2, one has:

- If Pnet $(\mathrm{t})<\mathrm{P}_{\text {Diesel_min }}$, two scenarii can occur:

If the PV energy generated by the inverter $\left(\mathrm{P}_{\text {output inverter }}(\mathrm{t})\right)$ is less than the power that must be cut $\left[\mathrm{P}_{\text {Diesel_min }}-\mathrm{P}_{\text {net }}(\mathrm{t})\right]$ in order to keep output power of DG $\mathrm{P}_{\text {Diesel }}(\mathrm{t})$ higher than their minimal set point value, all the PV energy generated is cut off. In this situation, the DG alone will supply the load.

$$
\mathrm{P}_{\text {inverter_limit }}(\mathrm{t})=0
$$

If $\mathrm{P}_{\text {output inverter }}(\mathrm{t})$ is higher than $\left[\mathrm{P}_{\text {Diesel min }}-\mathrm{P}_{\text {net }}(\mathrm{t})\right]$, the $\mathrm{PV}$ energy generated from inverter is reduced. In this case:

$$
\mathrm{P}_{\text {inverter_limit }}(\mathrm{t})=\mathrm{P}_{\text {output_inverter }}(\mathrm{t})-\left[\mathrm{P}_{\text {Diesel_min }}-\mathrm{P}_{\text {net }}(\mathrm{t})\right]
$$

- If $\mathrm{P}_{\text {net }}(\mathrm{t}) \geq \mathrm{P}_{\text {Diesel_min, }}$ two situations can occur:

If $\left[P_{\text {Load }}(t)-P_{P V}(t)\right]$ is higher than $P_{\text {Diesel_min, }}$ the inverter output power limit is set at its nominal output value.

$$
\mathrm{P}_{\text {inverter_limit }}(\mathrm{t})=\mathrm{P}_{\text {inverter_nominal }}
$$

This step aims to increase the PV power penetration when the PV energy estimated is higher than the output power from the inverter at that time.

If $\left[P_{\text {Load }}(t)-P_{P V}(t)\right]$ is less than $P_{\text {Diesel_min, }}$ the inverter active power limit is evaluated as:

$$
\mathrm{P}_{\text {inverter_limit }}(\mathrm{t})=\mathrm{P}_{\text {Load }}-\mathrm{P}_{\text {Diesel_min }}
$$

\subsection{Energy Management Strategy 3: Control with Controllable loads}

In this strategy, whenever the PV energy is higher than the load demand or the DG is in a situation to operate under its minimal output value, the controllable loads are connected to the system to consume the surplus of PV energy generated and consequently allow the DG to operate up its minimal output set point. The flowchart of the control strategy developed in this case is displayed in Figure 3.

$$
\mathrm{P}_{\text {output_inverter }}=\mathrm{P}_{\mathrm{PV}_{\_} \mathrm{STC}} *\left(\frac{\mathrm{G}}{\mathrm{G}_{\mathrm{STC}}}\right) *\left[1+K_{t} *\left(\mathrm{~T}_{\text {cell }}-\mathrm{T}_{\text {cell_STC }}\right)\right] * \eta_{\text {inverter }}
$$

Where:

$\mathrm{P}_{\text {output_inverter }}(\mathrm{kW})$ is the output power of the inverter,

$\mathrm{P}_{\text {pv_STC }}(\mathrm{kW})$ is the output power of the PV array under standard test conditions (STC),

$\mathrm{G}\left(\mathrm{W} / \mathrm{m}^{2}\right)$ is the local global solar radiation,

$\mathrm{G}_{\mathrm{STC}}\left(\mathrm{W} / \mathrm{m}^{2}\right)$ is global solar radiation under STC conditions. $\mathrm{K}_{\mathrm{t}}\left({ }^{\circ} \mathrm{C}^{-1}\right)$ is the temperature coefficient,

$\mathrm{T}_{\text {cell_STC }}\left({ }^{\circ} \mathrm{C}\right)$ is cell temperature under standard test conditions,

$\eta_{\text {inverter }}$ is the inverter efficiency.

$\mathrm{T}_{\text {cell }}\left({ }^{\circ} \mathrm{C}\right)$ is the PV cell operation temperature $\left({ }^{\circ} \mathrm{C}\right)$.

This latter can be expressed by:

$$
\mathrm{T}_{\text {cell }}=\mathrm{T}_{\mathrm{amb}}+\left(\frac{\mathrm{G}}{G_{N O C T}}\right) *\left(\mathrm{NOCT}-\mathrm{T}_{\mathrm{amb}_{\mathrm{NOCT}}}\right)
$$

$\mathrm{T}_{\mathrm{amb}}\left({ }^{\circ} \mathrm{C}\right)$ is the ambient temperature, NOCT is the
For the performance evaluation of the energy management strategies proposed, the mathematical model of each component of the hybrid PV/Diesel system considered for the simulation is necessary. These models are presented in subsequent sections.

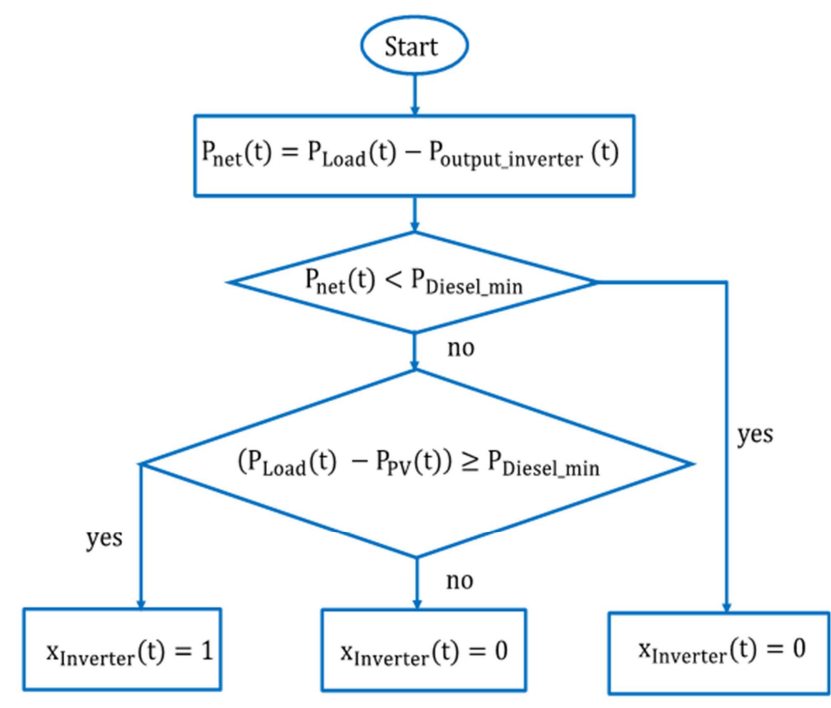

Figure 3. Flowchart of control strategy with controllable loads.

\section{Mathematical Models of Hybrid PV/Diesel System Components}

\subsection{PV generator (PVArray + Inverter)}

It is well known that a PV array produces DC current. However, many electrical appliances use AC current. Therefore, the DC current is, very often, converted into AC current. The inverter is the device that converts the power flow from the DC current to the AC current. The AC output power of the inverter is expressed as it follows $[10,11]$ :

nominal cell operating temperature $\left({ }^{\circ} \mathrm{C}\right)$ which is measured under $\mathrm{G}_{\text {NOCT }}=800 \mathrm{~W} / \mathrm{m}^{2}$ and $\mathrm{T}_{\text {amb_NOCT }}=20^{\circ} \mathrm{C}$. NOCT is given by manufacturers

\subsection{Diesel Generators Model}

A Diesel generator is widely modeled by its hourly fuel consumption. This later is deeply linked to the output power produced and the rated power of the DG. In this study the following linear approximation has been used $[4,5]$.

$$
\mathrm{f}(\mathrm{t})=\mathrm{a} * \mathrm{P}_{\text {Diesel }}(\mathrm{t})+\mathrm{b} * \mathrm{P}_{\text {Diesel_nominal }}
$$

Where $f(t)$ is the hourly fuel consumption in $L / h$; $\mathrm{P}_{\text {Diesel }}(\mathrm{t})$ is the output power of the DG;

$\mathrm{P}_{\text {Diesel_nominal }}$ is the rated power of diesel generator. $a$ and $b$ are constants parameters of diesel generators. 


\section{Experimental Setup and Case Study}

\subsection{Experimental Setup}

The experimental validation of the energy management strategies developed is performed under the microgrid platform at the National Institute for Solar Energy (CEAINES) in France (see Figure 4).

The microgrid experimental platform includes:

- One Diesel generator (400/230 V, $50 \mathrm{~Hz}, 35 \mathrm{~kW})$

- A PV emulator; it is used to simulate PV production for different climate conditions. It's maximal output power is $10 \mathrm{kWp}$,

- One SMA inverter (25 kW ),

- A loads bank of resistors of $88 \mathrm{kVA}$ as maximal active power; that is used to simulate the load profile considered.

- A variable electronic load with active power ranging from 0 to $10 \mathrm{~kW}$ used as controllable loads.

The platform monitoring, control-command and data acquisition is made with the SCADA unit developed with Labview software. The communication protocol used is the standard TCP/IP Modbus protocol. All the energy management strategies developed are implemented with the Matlab environment. For the tests, 5 minutes has been chosen as sampling period and corresponds to 1 hour in real conditions. Thus, the daily load profile has been run over 2 hours during the experiments.

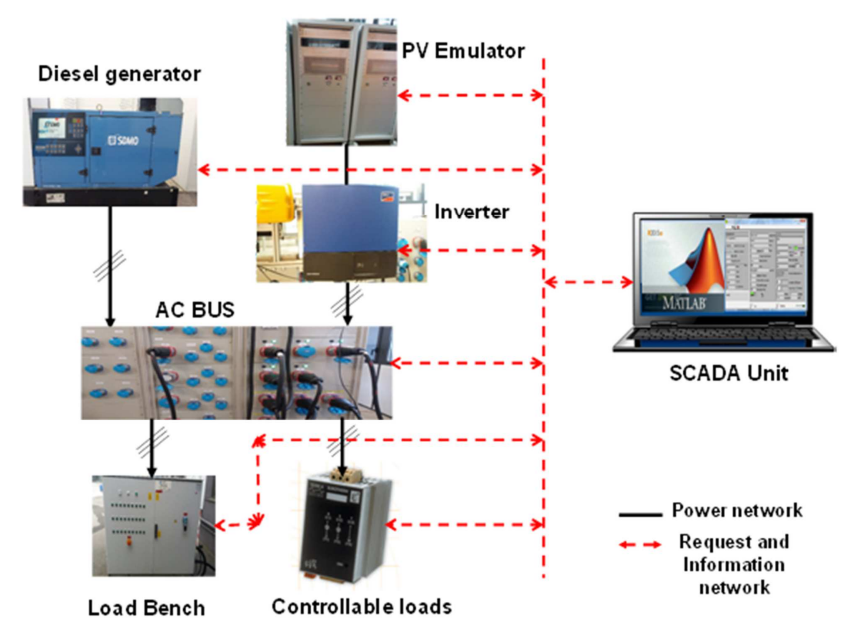

Figure 4. Microgrid experimental platform at INES.

\subsection{Case of Study: Load Profile and Climate Data}

The load profile that is taken account in this study and shown in Figure 5 is typical of sub-Saharan Africa rural areas. The daily energy demand is $187 \mathrm{kWh}$ with $17 \mathrm{~kW}$ as the load peak value.

For the purpose of evaluating the performance of the proposed control strategies, two different climate conditions are considered (one for a cloudy day and the second for a sunny day) for simulation and experiment analysis.

Figures 6 and 7 display the global solar radiation and ambient temperature profiles for respectively cloudy and sunny days. The parameters of simulations and experimental analysis are presented in Table 1.

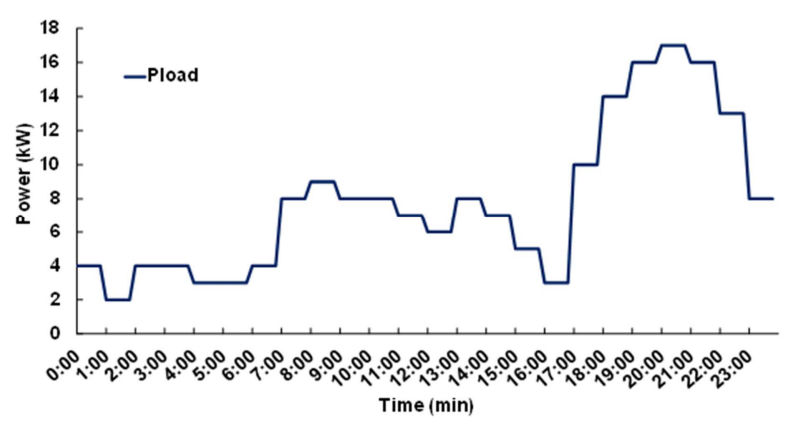

Figure 5. Daily rural areas load profile.

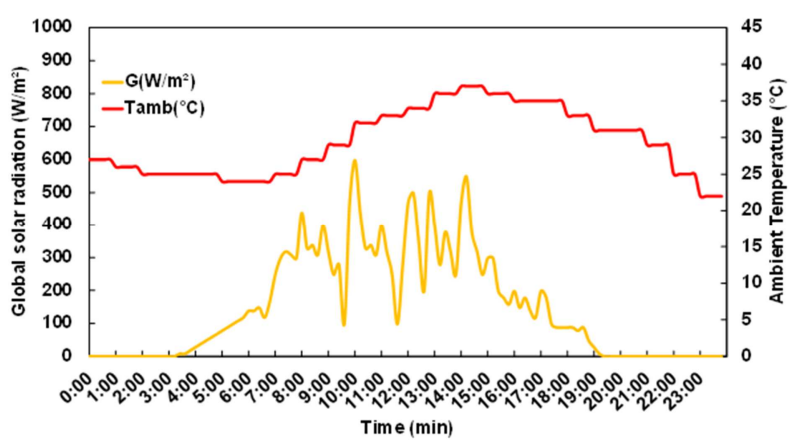

Figure 6. Global solar radiation and ambient temperature profiles of a cloudy day.

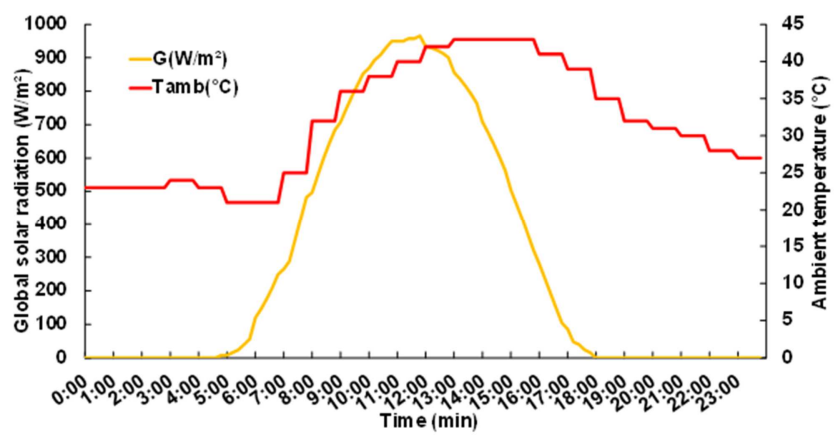

Figure 7. Global solar radiation and ambient temperature profile of a sunny day.

Table 1. Simulation and experimental parameters.

\begin{tabular}{ll}
\hline Simulation and experimental parameters & Values \\
\hline Nominal power of Diesel generator $(\mathrm{kW})$ & 35 \\
Minimal output power of DG set point $(\mathrm{kW})$ & 1 \\
a: Diesel generator fuel factor $(\mathrm{L} / \mathrm{kWh})$ & 0.246 \\
b: Diesel generator fuel factor $(\mathrm{L} / \mathrm{kWh})$ & 0.084 \\
Nominal power of inverter $(\mathrm{kW})$ & 25 \\
NOCT $\left({ }^{\circ} \mathrm{C}\right)$ & 45 \\
$\mathrm{Kt}\left({ }^{\circ} \mathrm{C}\right)$ & 0.004 \\
Carbon emission factor $(\mathrm{kg} / \mathrm{kWh})$ & 0.34 \\
\hline
\end{tabular}

\section{Results and Discussion}

To assess the performance of the control strategies studies, both simulation and experimental results are presented and discussed. 


\subsection{Simulation Results}

\subsubsection{Energy Flow Balance of the Hybrid PV/Diesel System with Inverter ON/OFF Control Strategy}

Figure 8 shows the energy flow balance for a cloudy day with inverter ON/OFF control strategy. It can be noticed that at any time, the load demand has been supplied by the diesel generator alone or by both diesel and PV generators. The minimal output power from DG during this day is obtained at $16 \mathrm{~h}$ and equal to $1.5 \mathrm{~kW}$. This value is higher than the minimal output set point assumed to $1 \mathrm{~kW}$. In this case, no PV energy curtailment has been observed and all the PV energy produced and generated through the inverter is consumed.

On the sunny day, especially from $9 \mathrm{~h}$ to $14 \mathrm{~h} 30,15 \mathrm{~h}$ to $15 \mathrm{~h}$ 30 and $16 \mathrm{~h}$ to $16 \mathrm{~h} 15$ as shown in Figure 9, when the remaining power to be supplied by the DG is lower than its minimal output set point, the PV inverter is disconnected from the system. No PV energy has been generated by the inverter to the system in this period. The load is supplied only by the diesel generator. It can be observed that an important amount of PV energy has been wasted under this strategy.

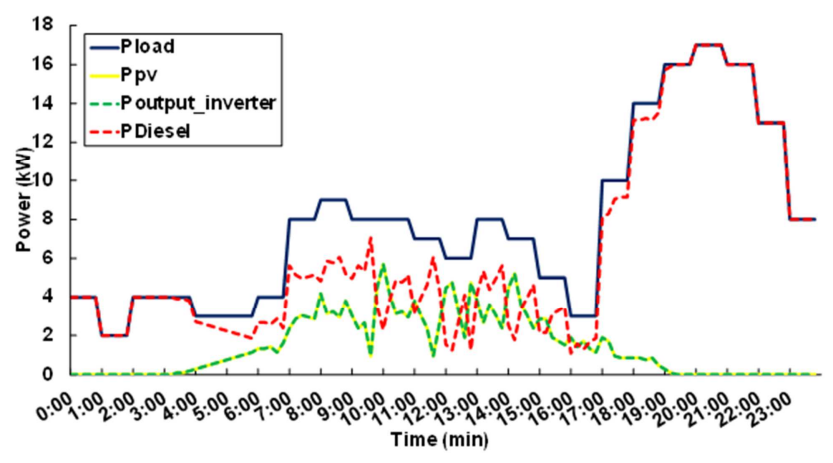

Figure 8. Simulation of energy flow balance on cloudy day.

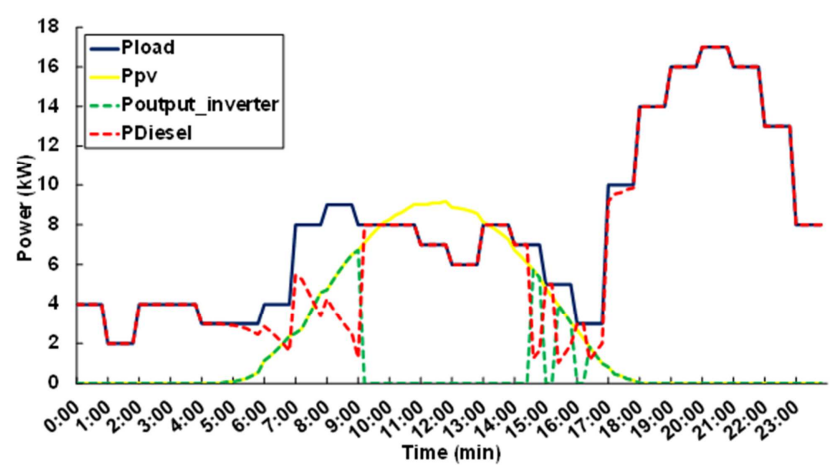

Figure 9. Simulation of energy flow balance in sunny day under inverter ON/OFF control strategy.

\subsubsection{Energy Flow Balance Under inverter Active Power Control Strategy}

On the cloudy day, the energy flow balance for this strategy leads to the same results as those of the inverter ON/OFF control strategy presented in figure 8.

On the sunny day, the system's operation under inverter active power control strategy proposed is shown in figure 10 . Comparing to the inverter ON/OFF control strategy, from $9 \mathrm{~h}$ to $14 \mathrm{~h} 30,15 \mathrm{~h}$ to $15 \mathrm{~h} 30$ and $16 \mathrm{~h}$ to $16 \mathrm{~h} 15$, the PV energy produced through the inverter is controlled as well as possible in order to keep the output power of diesel generator at least equal to the minimal set point.

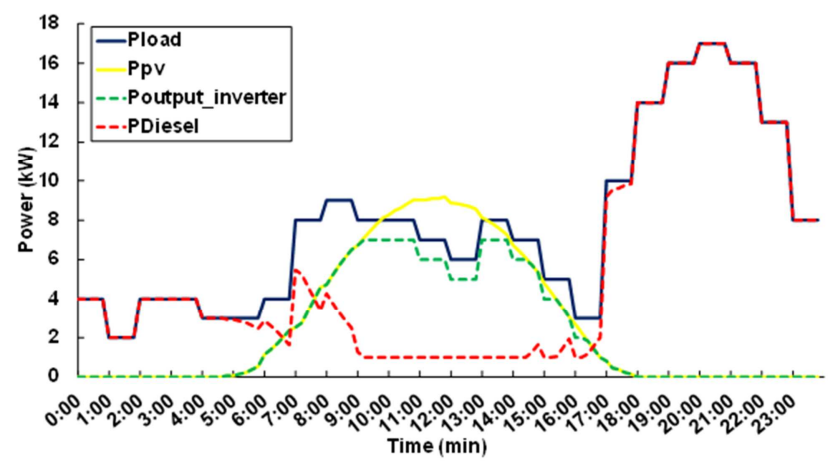

Figure 10. Simulation of energy flow balance on sunny day under active power control strategy.

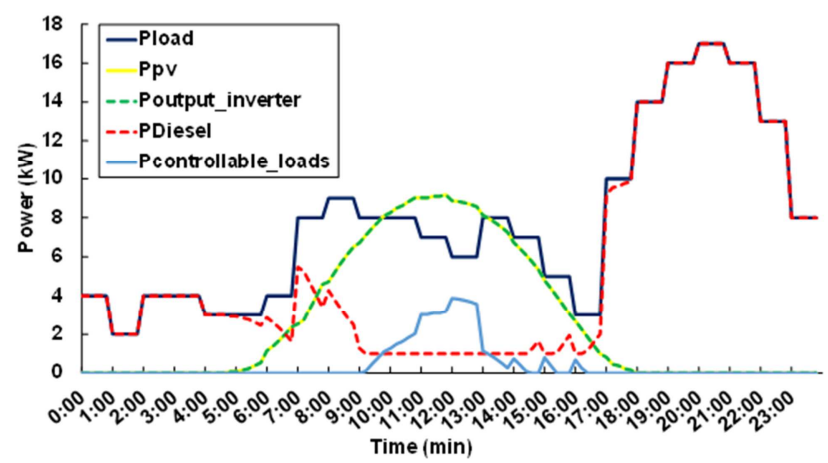

Figure 11. Simulation of energy flow balance on sunny day under control strategy with controllable loads.

\subsubsection{Energy Flow Balance Under Strategy with Controllable Loads}

As described in sub-section 2.3, the controllable loads have been used especially to consume the surplus of PV energy and then avoid the operation of DG under its minimal output power set point. Under this strategy, since the minimal DG output power observed $(1.5 \mathrm{~kW})$ on the cloudy day is higher than the minimal set point value, no controllable load is needed for the system management. Figure 11 presents the daily operation of the hybrid system under this strategy on the sunny day. The effectiveness of the control approach can be observed. During the period for high PV energy and low load demand, the controllable loads power need is evaluated and connected to the hybrid energy system. The Diesel generator at this instance runs at least at its minimal output power set point.

From the simulation results obtained, the impact for each of the control strategies on solar energy fraction and on carbon emission are investigated and compared in the following sub-section.

\subsubsection{Effect of Control Strategies on Solar Energy Fraction}

In order to investigate the effect of each strategy on solar energy penetration in the energy system, the solar energy fraction $\left(F_{P V}\right)$ is selected as criteria. It is defined as the ratio of solar energy consumed to the total energy production of the hybrid system. The equation for solar energy fraction 
evaluation is shown as follows in [12].

$$
F_{P V}=\frac{E_{P V}}{E_{P V}+E_{\text {Diesel }}} * 100
$$

On the sunny day and as presented in Figure 12, the control strategy with controllable loads offers the high value $(34 \%)$ of solar energy fraction. This is the ideal approach to avoid solar energy curtailment and to ensure reliable operation to the whole system.

However, for control strategies without controllable loads, it is clear that the strategy proposed, which is based on active power control achieves more solar energy in the system than inverter ON/OFF control strategy. Almost $65 \%$ and $71 \%$ of the solar energy is wasted by using ON/OFF control strategy comparing respectively to inverter active power control strategy and control strategy with controllable loads-(Figure 12).

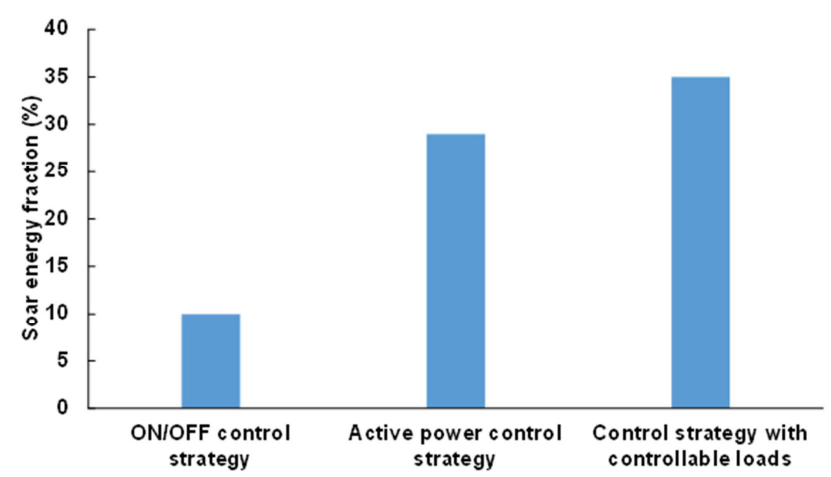

Figure 12. Solar energy fraction on sunny day for the control strategies studied.

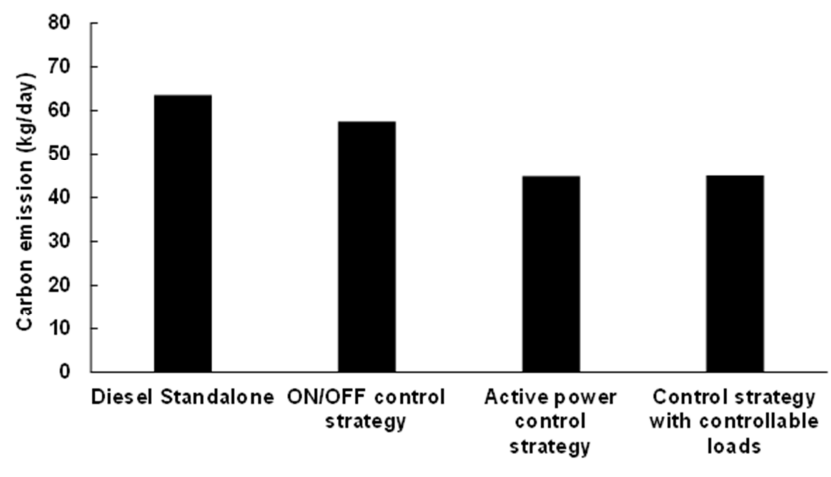

Figure 13. Carbon emission level.

\subsubsection{Effect of Control Strategies on Carbon Emissions Level}

The most important environmental benefit of the PV system is its carbon emission reduction resulting in a cleaner and less polluted environment that has a great impact on people's lives [6]. The impact of the control strategies proposed in this study is evaluated and compared to diesel standalone system. Figure 13 shows that the lower amount of carbon (almost the same value: $45 \mathrm{~kg} / \mathrm{day}$ ) is generated under the inverter control active power strategy and control strategy with controllable loads. Respectively $22 \%$ and $30 \%$ of carbon has been eliminated under inverter active power control strategy, control strategy with controllable loads comparing to inverter ON/OFF control strategy and the diesel standalone system. It appears clearly that the control strategies proposed based on the controllable loads and on the inverter active power control contribute to reduce the carbon emission.

\subsection{Experimental Results}

Due to the advantages and the effectiveness of the proposed strategies comparing to inverter ON/OFF control strategy based on the simulation results previously presented, their experimental validation has been performed in this subsection. First, the energy flow balance under these strategies for the cloudy and sunny day are presented and discussed. Finally, the power quality of the electricity produced has been monitored by measuring the voltage and frequency.

\subsubsection{Energy Flow Balance from Experimental Analysis}

i. Inverter active power control strategy

On the cloudy day, the experimental results obtained have shown the dynamic of the DG to supply the load at any time (Figure 14). From 9h35 to $10 \mathrm{~h} 35$ when more fluctuations of PV energy is observed, the DG supplies the load as well as possible without interruption. This result highlights the ability of the DG to offer a better dynamic and ensure reliable operation of the whole system. A similar results was obtained from the simulation as presented previously on figure 8 for the cloudy day.

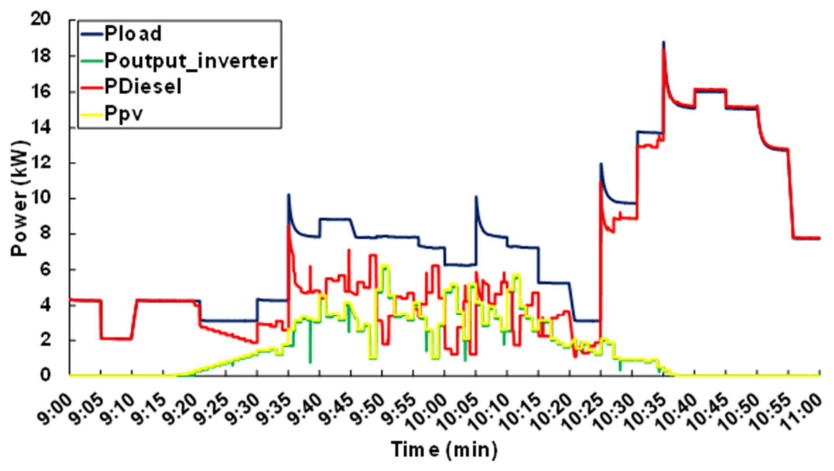

Figure 14. Experimentation of energy flow balance on cloudy day under inverter active power control.

As displayed in Figure 15, the control strategy based on inverter active power control proposed correctly manages the energy in hybrid PV/Diesel as expected from the simulation results. The inverter output power has been controlled from $14 \mathrm{~h}$ to $14 \mathrm{~h} 30$ in order to ensure better operation to the system especially when PV energy $\left(\mathrm{P}_{\mathrm{pv}}\right)$ becomes more than the load demand ( $\left.\mathrm{P}_{\text {load }}\right)$.

ii. Control strategy with controllable loads

The operation of the hybrid PV/Diesel energy system with the control strategy based on the controllable loads is presented in figure 16 for the sunny day. The experimental results have demonstrated the feasibility of controllable loads use to avoid reserve power on the diesel generator and at the same time to consume the total PV energy produced by the system. 


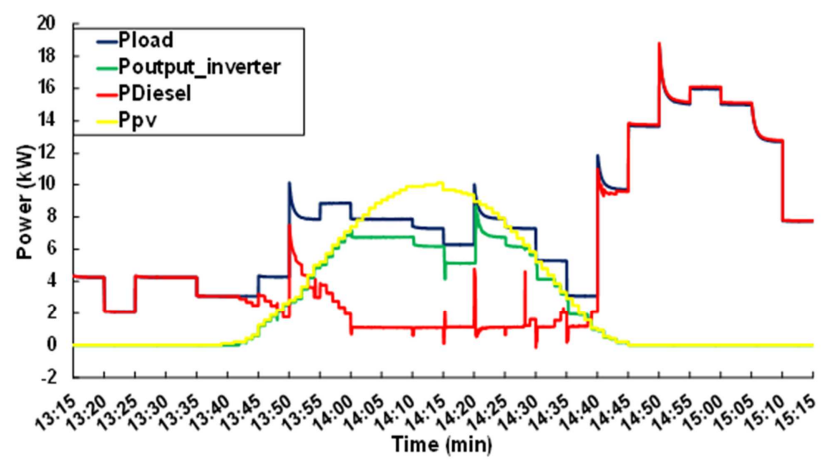

Figure 15. Experimentation of energy flow balance on sunny day under inverter active power control.

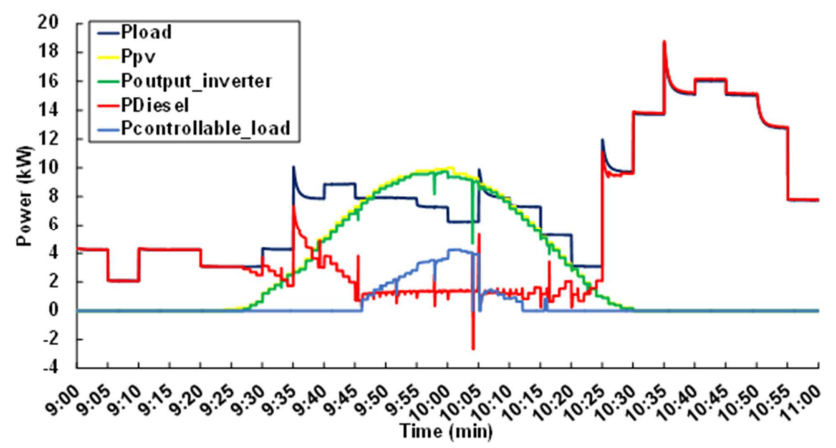

Figure 16. Experimentation of energy flow balance on sunny day under control with controllable loads.

\subsubsection{Voltage and Frequency Fluctuation from Experimental Analysis}

The integration of a PV system into a microgrid like hybrid PV/Diesel system including a diesel generator can have significant impacts on power quality in general and especially on voltage and frequency as investigated in [8]. In the following sub-section, the energy system's frequency and voltage under the energy management strategies proposed are presented and discussed.

i. Inverter active power control strategy

- Frequency fluctuation

Figures 17 and 18 display the frequency fluctuation in the microgrid respectively on the cloudy and sunny day. The frequency fluctuation can be observed during the operation of the energy system. It is clear that, the variation of diesel generator output power influences the system's frequency value. In fact, when the diesel output power increased, the frequency dropped slightly and vice versa. The frequency as well as on the cloudy and sunny days with this control strategy ranged between 49.3 and $50.2 \mathrm{~Hz}$. It was also found from the tests that, the frequency has a good dynamic and did not deviate out of the acceptable range $50 \pm 4.5 \mathrm{~Hz}$ as recommended in [13] for off-grid PV systems.

- Voltage fluctuation

The voltage values in the three-phase hybrid energy system under inverter active power control strategy in cloudy day and on the sunny day are respectively plotted in figures 19 and 20. Additionally on the cloudy day and sunny day under this strategy, the voltage value during the tests ranged from $225.5 \mathrm{~V}$ to $231 \mathrm{~V}$. According to the standard EN 50160, the variation of the voltage should be in the range of $\pm 10 \%$ of the nominal value $(230 \mathrm{~V})$ [8]. On the two days considered the same voltage fluctuation level in the order of $2 \%$ has been observed.

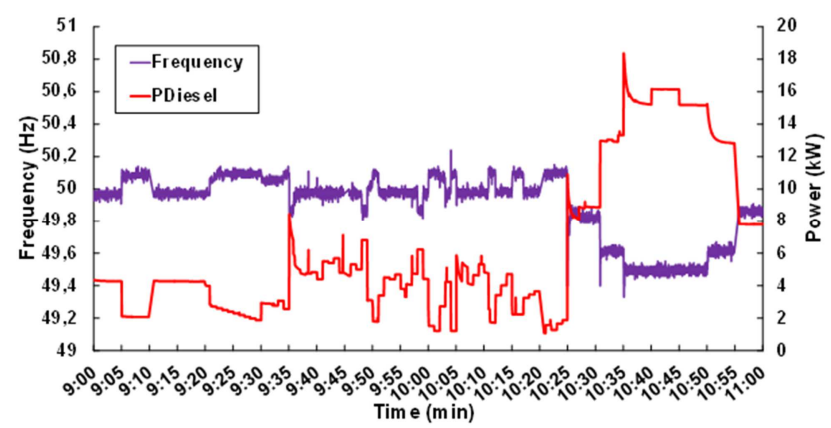

Figure 17. Frequency fluctuation on cloudy day under inverter active power control strategy (experimental).

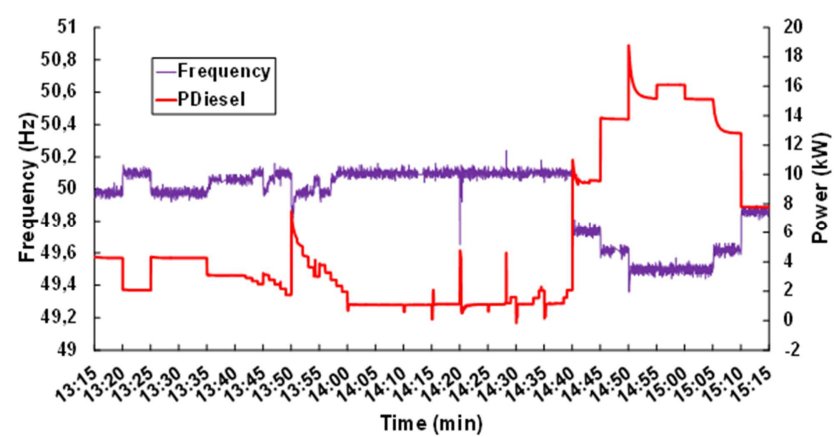

Figure 18. Frequency fluctuation on sunny day under inverter active power control strategy (experimental).

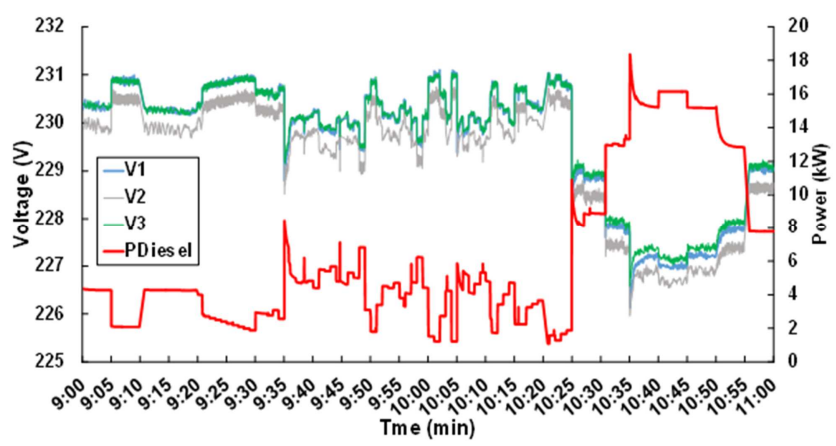

Figure 19. Voltage fluctuation on cloudy day under inverter active power control strategy (experimental).

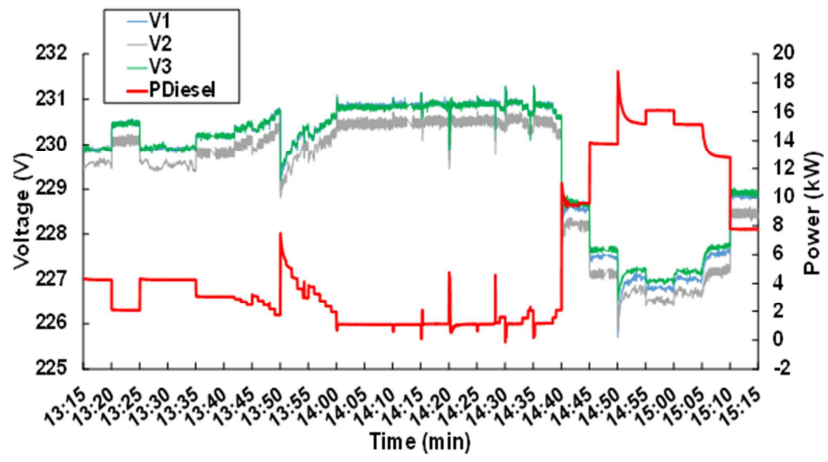

Figure 20. Voltage fluctuation on sunny day under inverter active power control strategy (experimental). 
ii. Control strategy with controllable loads

- Frequency fluctuation

With controllable loads control strategy too, the frequency fluctuate according to the output power of the diesel generator as show in figure 21 for the sunny day. The controllable loads output power connected to the system has no impact on the frequency. This latter is around it nominal value $(50 \mathrm{~Hz})$ during that time (from $09 \mathrm{~h} 45$ to $10 \mathrm{~h} 15$ ).

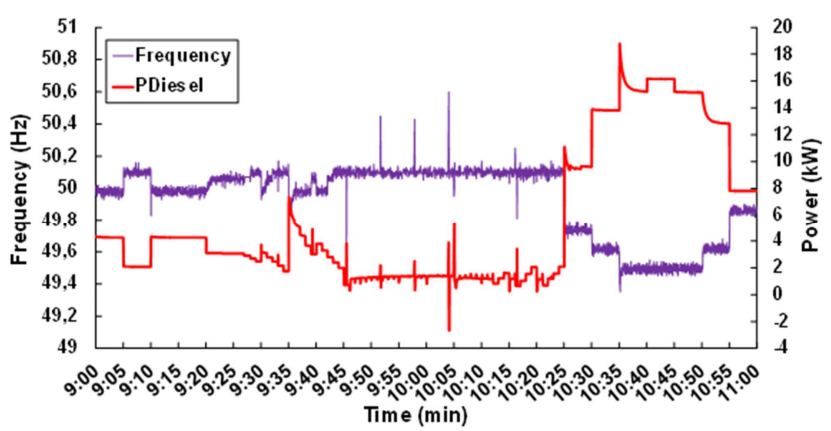

Figure 21. Frequency fluctuation on sunny day under control strategy with controllable loads (experimental).

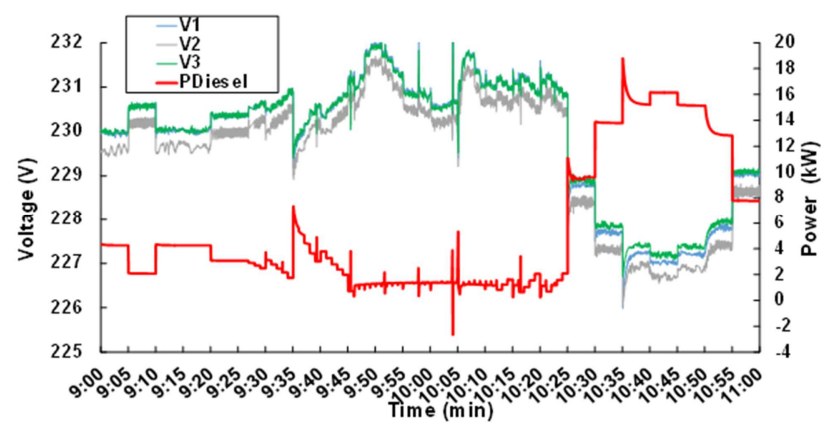

Figure 22. Voltage fluctuation on sunny day under control strategy with controllable loads (experimental).

\section{- Voltage fluctuation}

Although the frequency was stable when the controllable loads were connected to the system, some weak fluctuations on the system's voltage were observed. Indeed, as we can see in figure 22 , the voltage has increased from its nominal value $(230 \mathrm{~V})$ to $231.8 \mathrm{~V}$. this means that, the voltage has fluctuated just $1 \%$ in that period. This fluctuation level is too slight compared to the standard fluctuation level.

Based on the power quality analysis results, it can be summarized that the two control strategies based respectively on inverter active power control and on the controllable loads use does not deteriorate the system stability.

\section{Conclusion}

The present work presents a simulation and experimental analysis of energy management control strategies for a hybrid PV/Diesel energy system. The proposed control strategies based on inverter active power control and on the controllable loads use have been presented and applied to a typical rural loads profile under two different climate conditions. The simulation results compared to inverter
ON/OFF control strategy have shown a good performance of the strategies proposed especially when high PV generation and low load demand occur. From this experimental analysis, the effectiveness of the control strategies proposed has also been demonstrated in term of energy flow balance and of the system's stability. In future work, this control strategies approach for energy management will be applied to hybrid PV/Diesel energy systems including several inverters and several diesel generators.

\section{Acknowledgments}

Authors want to thank the European Union Commission through the Energy Facility II, the International Institute for Water and Environmental Engineering (2iE) and the National Institute for Solar Energy (INES)-France for their financial support of this study. The Authors are also grateful to Mrs Jessica Ouedraogo of the 2iE - Penn State Centre for the english polishing of this paper.

\section{References}

[1] U. Suresh Kumar and P. S. Manoharan, "Economic analysis of hybrid power systems (PV/diesel) in different climatic zones of Tamil Nadu," Energy Convers. Manag., vol. 80, pp. 469476, 2014.

[2] S. M. Shaahid and I. El-Amin, "Techno-economic evaluation of off-grid hybrid photovoltaic-diesel-battery power systems for rural electrification in Saudi Arabia-A way forward for sustainable development," Renew. Sustain. Energy Rev., vol. 13, no. 3, pp. 625-633, Apr. 2009.

[3] International Energy Agency, "World Energy Outlook (WEO)." 2013.

[4] D. Tsuanyo, Y. Azoumah, D. Aussel, and P. Neveu, "Modeling and optimization of batteryless hybrid PV (photovoltaic)/Diesel systems for off-grid applications," Energy, pp. 1-12, 2015.

[5] D. Yamegueu, Y. Azoumah, X. Py, and N. Zongo, "Experimental study of electricity generation by Solar $\mathrm{PV} /$ diesel hybrid systems without battery storage for off-grid areas," Renew. Energy, vol. 36, pp. 1780-1787, 2011.

[6] B. I. Ouedraogo, S. Kouame, Y. Azoumah, and D. Yamegueu, "Incentives for rural off grid electrification in Burkina Faso using LCOE," Renew. Energy, vol. 78, pp. 573-582, 2015.

[7] K. Y. Lau, M. F. M. Yousof, S. N. M. Arshad, M. Anwari, and a. H. M. Yatim, "Performance analysis of hybrid photovoltaic/diesel energy system under Malaysian conditions," Energy, vol. 35, no. 8, pp. 3245-3255, 2010.

[8] D. Yamegueu, Y. Azoumah, X. Py, and H. Kottin, "Experimental analysis of a solar PV/diesel hybrid system without storage: Focus on its dynamic behavior," Int. J. Electr. Power Energy Syst., vol. 44, pp. 267-274, 2013.

[9] D. Alfonso, H. E. Ariza, J. C, a Correcher, G. Escriv, R. Roig, C. Rold, I. Segura, C. Vargas, E. Hurtado, and F. Ib, "Experimental veri fi cation of hybrid renewable systems as feasible energy sources n,” vol. 86, pp. 384-391, 2016. 
14 Gabin Koucoi et al.: Energy Management Strategies for Hybrid PV/Diesel Energy Systems: Simulation and Experimental Validation

[10] A. Kaabeche, M. Belhamel, and R. Ibtiouen, "Technoeconomic valuation and optimization of integrated photovoltaic/wind energy conversion system," Sol. Energy, vol. 85, pp. 2407-2420, 2011.

[11] M. S. Ismail, M. Moghavvemi, and T. M. I. Mahlia, "Technoeconomic analysis of an optimized photovoltaic and diesel generator hybrid power system for remote houses in a tropical climate," Energy Convers. Manag., vol. 69, pp. 163-173, 2013.
[12] N. A. Luu, "Control and management strategies for a microgrid", Thèse de doctorat, Université de Grenoble, 2015.

[13] SMA, "PV Inverters - Use and Settings of PV Inverters in OffGrid Systems,

http://www.sma.de/en/products/solarinverters/sunny-tripower20000tl-25000tl.html\#Downloads-108649," pp. 2-5. 